\title{
Addressing the Challenges of Pathogen Evolution on the World's Arable Crops
}

\author{
Jeremy J. Burdon, Jiasui Zhan, Luke G. Barrett, Julien Papaix, and Peter H. Thrall
}

First and second authors: Fujian Key Lab of Plant Virology, Institute of Plant Virology; Fujian Agriculture and Forestry University, Fuzhou, China; first, third, and fifth authors: CSIRO Agriculture, PO Box 1600, Canberra, A.C.T. 2601, Australia; and fourth author: INRA Biostatistics and Spatial Processes, Domaine Saint-Paul AgroParc, 84914 Avignon, France.

Accepted for publication 17 June 2016.

\begin{abstract}
Burdon, J. J., Zhan, J., Barrett, L. G., Papaï, J., and Thrall, P. H. 2016. Addressing the challenges of pathogen evolution on the world's arable crops. Phytopathology 106:1117-1127.

Advances in genomic and molecular technologies coupled with an increasing understanding of the fine structure of many resistance and infectivity genes, have opened up a new era of hope in controlling the many plant pathogens that continue to be a major source of loss in arable crops. Some new approaches are under consideration including the use of

manipulation through marker and gene editing technologies and to lock a range of resistance genes together in simply manipulable resistance gene cassettes. All these approaches essentially continue a strategy that assumes the ability to construct genetic-based resistance barriers that are insurmountable to target pathogens. Here we show how the recent advances in knowledge and marker technologies can be used to generate more durable disease resistance strategies that are based on broad evolutionary principles aimed at presenting pathogens with a shifting, landscape of fluctuating directional selection.
\end{abstract} nonhost resistance and the targeting of critical developmental constraints. However, the major thrust of these genomic and molecular approaches is to enhance the identification of resistance genes, to increase their ease of
Additional keywords: gene deployment strategies, infectivity, qualitative resistance, quantitative resistance, varietal mixtures.
Pathogen evolutionary change represents a fundamental issue with regard to controlling infectious disease in the world's arable crops. The challenge to science is to stop or, at least, reduce the rate at which pathogens evolve to overcome host resistance. This challenge is compounded by demands to generate more effective and durable control in the face of an ongoing search for higher productivity, societal expectations that restrain the application of genetically modified (GM) approaches and limited genetic resources. Here, we examine current paradigms for disease control and suggest that more explicit evolutionary and epidemiological management approaches are needed. As discussed below, technological advances are enabling a broader range of options for 'packaging' host resistance in new crop cultivars. However, we generally lack the ability to predict the consequences of different gene packaging approaches under different spatio-temporal deployment strategies. Moreover, a key consideration is that strategies that optimize within-season epidemiological control may be in conflict with strategies that optimize longterm evolutionary control of pathogens (Box 1).

\section{EVOLUTION OF RESISTANCE AND INFECTIVITY}

Antagonistic interactions represent ubiquitous forces shaping the nature, intensity, and direction of ecological and evolutionary dynamics in both natural and managed ecosystems. In natural systems, reciprocal coevolution occurs as a result of selective pressures imposed by each partner and the environment. However, in human-mediated interactions, such as with crop pathogens, evolutionary trajectories may be significantly modified by practices that change the susceptibility of host individuals to infection or alter opportunities for pathogen development and disease spread (Brown 2015; Lo Iacono et al. 2012;

Corresponding author: J. Burdon: E-mail address: jeremy.burdon@csiro.au
Mundt 2014; Zhan et al. 2002). Research conducted in natural plantpathogen associations has important lessons for understanding resistance durability in agricultural scenarios (Burdon and Thrall 2014). Chief among these is the nearly ubiquitous maintenance of high levels of genetic variation for pathogen infectivity (Tack et al. 2012) and the corresponding rarity of universally resistant host lines (Laine et al. 2011) (Note: we use here the term 'infectivity' rather than 'virulence' because of the latter term's confusing use in plant pathology in a general sense). This suggests that, for most crop resistance $(R)$ genes recovered from land races or wild relatives, there exists, somewhere, a corresponding gene for pathogen infectivity and the strong potential to evolve new infectivity. A second key point is the central role that spatio-temporal heterogeneity in the distribution of host resistance plays in determining patterns of disease and pathogen evolution (Tack et al. 2014).

While a continuum exists between natural and agricultural plant host-pathogen associations, there are some fundamental differences. First, the dynamics of disease and the selective impact of pathogens are markedly different (Zhan et al. 2015). Most wild plant populations are relatively ephemeral and distributed in multiple small demes within variable landscapes. Long-term persistence of such systems, which often contain a high diversity in host and pathogen traits associated with disease occurrence, is built on a complex mosaic of temporal and spatial interactions (Burdon and Thrall 2009, 2014; Laine and Hanski 2006; Lebeda et al. 2008; Thrall et al. 2012). In these circumstances, evolutionary change ranges from simple variation in gene frequencies to abrupt multigenic shifts following local extinctions. In contrast, breeding and management approaches in agricultural production systems have generally driven agronomic conditions supportive of reliable, high crop yields. The conditions primarily responsible for these outcomes-better nutrition and moisture status, genetic uniformity, large population sizes, high crop densities, and multiple croppinggenerate physical and environmental conditions that favor larger pathogen population sizes (and hence, increased evolutionary 
potential) through more efficient pathogen survival, reproduction, and spread (Zhan et al. 2014). In turn, the increased propensity for epidemic development places greater selection pressure on current chemical and genetic solutions (i.e., repeated deployment of new resistant crop cultivars) used in disease control. Where resistance fails rapidly, the agricultural community is often faced with ongoing 'boom and bust' cycles of disease severity and repeated loss of effectiveness of control measures (Johnson 1961).

\section{CURRENT GENETIC CONTROL APPROACHES}

Over the past century, attempts to control plant diseases in agriculture through genetic means have been dominated by the application of qualitative (major gene) and quantitative (multigenic) resistances. This has resulted in considerable discussion as to the relative value of these approaches, a debate that often degenerates into their portrayal as nonoverlapping alternatives. In reality, all varieties relying on major gene resistance also carry at least some quantitative resistance, although this is often not a specific target for selection and stacking both types of resistance into crop varieties can reduce the rate at which new infectivity emerges (Palloix et al. 2009).

Qualitative resistance. One of the most important approachespyramiding major resistance $(R)$ genes-has a checkered history of great success coupled with periodic failure (Johnson 1961; Wulff and Moscou 2014). Certainly the speed at which specific $R$ genes are overcome is quite variable, happening quickly in some cases and

\section{GLOSSARY}

Aggressiveness: a quantitative measure of pathogen development in the host. Multiple traits, including infection efficiency, toxin production, latent period, infectious period, and spore production, contribute to differences in the aggressiveness of different pathogen isolates. (Equivalent to virulence in the animal parasite literature).

Directional selection: a manifestation of natural selection in which a single phenotype is favored over others, leading to a shift in the allele frequency towards that phenotype over time. Directional selection decreases genetic variance in the population.

Evolutionary potential: the ability of a pathogen to evolve to circumvent natural (resistance genes) and human-derived (fungicides) control measures. The evolutionary potential of pathogen populations results from the interplay of five evolutionary forces, i.e., mutation, population size, genetic drift, gene (genotype) flow. and recombination system, that, together, determine the probability of pathogen evolution. (McDonald and Linde [2002a] provide an extensive discussion).

Fluctuating directional selection: temporal or spatial sequential shifts in the direction and intensity of selection, such that no one combination of traits or alleles gives rise to a most favored outcome for all the different selection regimes. Populations are held in an unstable dynamic maintained by the continuing existence of the differed selective forces. Note, this differs from the standard accepted definition of disruptive selection, in which intermediate phenotypes are often less fit than either extreme and are, hence, unlikely to feature prominently in a population.

Infectivity: whether or not a pathogen isolate can infect a given host line and generate a fully compatible reaction. Infectivity has the same meaning as 'virulence' as defined by van der Plank [1963] and widely used in the plant pathology literature. However, the use of virulence in this context is easily confused with its use in animal and human pathogen circles and its usage in everyday speech where it is means aggressiveness. rather slowly in others. The reasons for this are often unclear, although in many cases, it appears to be system-specific (i.e., depending on the biology of the pathogen, its interaction with local and regional environments, and even the specific $R$ genes involved). For example, in Australia, $S r 26$ in wheat provided effective resistance against Puccinia graminis for many years longer than expected (Watson 1981). However, the durability of $S r 26$ has been attributed to its deployment during a period of years in which environmental conditions were generally unfavorable for pathogen development. Under these conditions, pathogen populations were small and the probability of mutations to infectivity within the pathogen population and of those mutants subsequently establishing was very low.

The theoretical basis for using pyramiding strategies to control disease is simple. Through simultaneously deploying multiple independent $R$ genes within a cultivar, pathogens are presented with evolutionary hurdles that are orders of magnitude greater than for single $R$ genes. While this logic is hard to criticize when $R$ genes in pyramids are considered collectively, the average longevity of each $R$ gene may be no greater than when used singly. Accumulation of infectivity in asexual pathogens (Zhan et al. 2012) or random reshuffling of infectivity from different origins in recombining pathogens (de Jonge et al. 2013) could significantly reduce the expected longevity of $R$ gene pyramids. Furthermore, as pointed out by Mundt (1990), mutations to infectivity are not always independent. Regardless of theoretical concerns, a major flaw in pyramiding strategies is often found in their origin and construction. To drive productivity gains as quickly as possible, breeding programs typically build on pedigrees that have already given rise to contemporary varieties. As a consequence, varieties that contain complex multigene pyramids (e.g., five or more genes) are largely developed through incremental addition of one or two $R$ genes to existing ' $R$-gene stacks.' Critically, these have already been subjected to strong selection by pathogens in agricultural settings. For example, among the five $P$. graminis resistance genes $(\mathrm{Sr} 2, \mathrm{Sr} 5$, Sr6, Sr8a, and Sr36) deployed in the Australian wheat variety Songlen (McIntosh et al. 1995), only $\operatorname{Sr} 8 a$ was locally novel, as $\mathrm{Sr} 2$, an adult-plant resistance (APR) gene, was already deployed in a number of other varieties and $\mathrm{Sr} 5, \mathrm{Sr} 6$, and $\mathrm{Sr} 36$ were previously deployed in the widely used parental variety Timglen.

A significant complication associated with resistance-gene pyramids during breeding is introduced by epistatic interactions that result in the resistant reaction of one $R$ gene masking those of other $R$ genes. This, coupled with the unlinked nature of most $R$ genes, generates difficulties in tracking and maintaining multiple $R$ genes through the recurrent cycles of crossing and selection that occur during development of commercial varieties. With the advent of sophisticated genomic and molecular technologies and the development of 'perfect or near-perfect markers' (Mago et al. 2011), these phenotypic assessment difficulties can be overcome and screening for the presence of multiple $R$ genes can be automated. However, this still leaves a major breeding hurdle of simultaneously following multiple, independently segregating $R$ genes in populations in which resistance is only one of many breeder-selected targets (Wulff and Moscou 2014). Packaging $R$ genes into a single cassette (multigene cassette approach) that can then be easily handled in a breeding program is a viable solution to this problem (Zhu et al. 2012). It should be noted, though, that there are still significant technical issues associated with generation and successful deployment of large gene cassettes, especially into species like wheat (Wulff and Moscou 2014).

Early discussions and proposals regarding $R$ gene cassettes considered the use of truly novel $\mathrm{R}$ alleles that might be created through artificial changes in nucleotide-binding site leucine-rich repeat (NBS-LRR) domains associated with $R$-gene specificity (Dodds et al. 2006). The fundamental concept was to confront the pathogen with three or more $\mathrm{R}$ alleles that it had never previously encountered, thereby presenting it with a near insurmountable barrier (if the mutation rate for each matching infectivity gene is $1 \times$ $10^{-4}$, then the frequency of occurrence of a mutant possessing three 
independently inherited infectivity genes would be $1 \times 10^{-12}$, assuming no recombination in the pathogen). More recently the focus of the multigene cassette approach has expanded subtly (Ellis et al.2014), but in such a way as to potentially reduce the probability of long-term disease control. This refocus on the use of naturally occurring resistances has been driven by a confluence of two factors. First, societal resistance to GM technologies and the hope that cisgenic approaches using only naturally occurring genes from the same species will be more acceptable (Schouten et al. 2006); and second, because the construction of a tight cassette of naturally occurring $\mathrm{R}$ alleles and their targeted insertion into the plant is considerably easier with existing technology, as opposed to de novo engineering of new alleles.

The use of naturally occurring resistance raises concerns about the genetic structure of the pathogen populations such cassetteprotected varieties will encounter in the field. All naturally occurring resistance genes occur as a consequence of on-going coevolution with pathogens, and it is likely that matching infectivity exists in such populations. While populations may initially be thousands of kilometers distant, successful crop varieties or their resistances are adopted rapidly around the world and pathogens have a remarkable capacity for long-distance dispersal (Brown and Hovmøller 2002). Establishment on volunteers and alternative hosts on which sexual or asexual recombination may occur has further potential to generate new infectivity (Burdon et al. 1981). Major and abrupt changes in the infectivity spectrum of several pathogens have been reported, especially in situations in which recombination may be a factor. For example, the epidemic outbreak of wheat stem rust in east Africa in 1999 was caused by the appearance of Ug99, a pathotype with a broad infectivity spectrum, most probably originating through sexual recombination. Recombination between different form species of rusts may produce somatic hybrids with infectivity spectra that extend beyond either parental host species (Burdon et al. 1981; Luig and Watson 1972; Park and Wellings 2012) or may result in the de novo evolution of a new pathogen, as happened in the emergence of Pyrenophora tritici-repentis due to horizontal gene transfer of an infectivity gene (ToxA) from Septoria nodorum (Friesen et al. 2006). In the case of wheat rust control, there is a clear intention that APR genes, with their reputed greater durability, should be included in cassettes. However, while the mode of action of APR genes remains undetermined, not all are race nonspecific (McIntosh et al. 1995; Sthapit et al. 2012) and there have been recent reports of the defeat of some such genes (Caffier et al. 2014; Delmotte et al. 2014).

A further complication in $R$ gene pyramiding is to assess the current infectivity status of existing pathogen populations. Although infectivity is generally recessive and many pathogens are diploid or dikaryotic, assessments of pathogen structure are routinely conducted via surveys of phenotypic expression on host differentials. As a consequence, the actual occurrence of infective pathogen isolates in a population is often insufficient to provide a clear view of the pathogen population's short-term evolutionary potential.

Quantitative resistance. This approach to providing geneticbased disease control in crop varieties is based on the use of multiple gene inheritance, each often of small but additive phenotypic effect. These may impact a variety of pathogen developmental stages. Plants with such traits are variously labeled as showing partial resistance, incomplete resistance, or to be 'slow-rusting.' In the field, they incur disease, and epidemics generally develop more slowly than would be the case for fully susceptible cultivars. Over time, a dogma has developed that such resistance is durable and, consequently, it has been used in a wide range of crops (Parlevliet 2002). In this regard, it is important to recognize a fundamental difference in how qualitative and quantitative resistance is expressed and subsequent effects on pathogen evolution. Partial resistance based on one or more quantitative trait loci (QTL) imposes a distinctly different selection pressure in the intensity and direction of selection to major $R$-gene resistance that results in nonsporulating infections. The latter imposes strong mortality selection, while the former permits some reproduction and, thus, selects primarily for increasing pathogen fecundity (summed over time). Thus, quantitative resistance tends to erode in a more continuous manner over time, while the efficacy of major $R$ genes is usually lost abruptly through single step mutations or recombination events in the pathogen. Note though, where $R$ genes are incompletely expressed (i.e., the infection type reaction to a noninfective pathotype allows some sporulation), they may effectively impose fecundity selection while still imposing selection for the appearance of an infective pathotype (we return to this later).

Significant among-isolate variation in aggressiveness (defined as a quantitative measure of a pathogen's development involving multiple traits, including infection efficiency, latent period, infectious period, and spore production) has been observed in a number of agriculturally important fungal pathogens, such as Blumeria graminis (Villaréal and Lannou 2002), Leptosphaeria maculans (Johnson and Lewis 1994), Mycosphaerella graminicola (Cowger and Mundt 2002), Phytophthora infestans (Andrivon et al. 2007), Puccinia striiformis (Mboup et al. 2012), P. triticina (Pariaud et al. 2012), and Rhynchosporium secalis (Abang et al. 2006). In some cases, differences were detected through comparisons among pathogen isolates collected from different environments (e.g., M. graminicola [Zhan et al. 2007]). Careful assessment of specific components of aggressiveness (e.g., latent period, spore production) has shown differences even among pathogen isolates from the same population (Melampsora lini [Thrall and Burdon 2003], Puccinia coronata [Bruns et al. 2012], M. graminicola [Yang et al. 2013]). This raises the important question of how labile these traits are and what is the potential rate at which aggressiveness evolves? The answer to this question is of vital importance in evaluating the long-term effectiveness of disease control based on quantitative resistance. Given the differences found both within and among populations, it is highly likely that individual pathogen lineages have the capacity to evolve greater aggressiveness in response to selection imposed by quantitative resistance. Thus serial passage of Fusarium oxysporum vasinfectum isolates on the same cotton variety for 10 consecutive generations saw a notable increase in the aggressiveness of some lineages (Wang et al. 2008). However, at the population level, infection by multiple genotypes in close proximity may lead to different outcomes as a consequence of interisolate competition (Johnson and Taylor 1976). Recent work has shown that, in natural plant-pathogen systems, coinfection levels can be high and that this can drive increased aggressiveness and more severe disease epidemics in local populations (Susi et al. 2015). Given that crop hosts frequently support large and often diverse pathogen populations, such phenomena may also be important in agricultural systems.

\section{FUTURE GENETIC CONTROL APPROACHES}

Prior to the genomic revolution, the detection of race-specific $R$ genes was achieved through challenge by pathogen isolates with different infectivity spectra. A major step forward came with the identification of gene sequences associated with resistance genes, especially NBS domain sequences. This paved the way for the use of sequence homology to detect large numbers of resistance gene analogs (RGA) in the genomes of most plant species (Li et al. 2010). Indeed, the number of RGA and other defense-related genes identified through the application of genomics tools and their distribution in plant genomes is driving major leaps in understanding of their evolution and the interrelatedness of resistance to different pathogens (Krattinger et al. 2009). Likewise, pathogen genomics is contributing to understanding of the interrelatedness of different pathogen populations (Goss 2015) and their recent evolutionary background (Stukenbrock et al. 2011; Zaffarano et al. 2008) and is rapidly uncovering the complexity of pathogen 
infectivity processes and the extent to which effector candidates are conserved across related species (Nemri et al. 2014).

The linking of the two approaches - combined host and pathogen genomic studies-is demonstrating the complexity of interactions between pathogen effectors and host resistance and ways in which pathogens manipulate hosts through effectors (Rafiqi et al. 2012; Yang et al. 2016) and suggesting novel approaches to crop protection (Dangl et al. 2013; Dodds and Rathjen 2010; Michelmore et al. 2013). For example, the existence of susceptibility factors in some hosts to some pathogens (Boevink et al. 2016; Yang et al. 2016) suggests the possibility that, by altering these, we might prevent pathogen colonization. At the same time, the availability of whole host gene sequences is driving the rapid development of 'perfect markers' for use in plant breeding and selection and thoughts about alternative gene deployment strategies, such as gene cassettes. Choosing the optimal combination of different $R$ genes to combine requires knowledge of how they interact with one another and the pathogen genes with which they interact (Figueroa et al. 2016).

Clearly, NBS-LRR resistance genes will continue to play a central role in providing protection against many crop diseases. Molecular technologies can deliver perfect markers for targeted genetic variants, and in those crops in which concerns about GM technologies no longer prevent their use (currently essentially all arable crops other than small grain cereals), $R$ gene stacking that challenges pathogen populations to accumulate mutations in multiple effector genes is likely to become commonplace (Dangl et al. 2013). Indeed, the ways these $R$ genes are combined and the particular combinations used (Leach et al. 2001) will continue to increase in sophistication. Gene-editing approaches (Belhaj et al. 2015; Lawrenson et al. 2015) that allow rapid specific changes in individual genes open up the potential to relatively simply construct varieties with novel resistance gene combinations as well as truly isogenic mixtures in which the individual compounds differ only for specific resistances.

A variety of complex computational analyses of pathogen genome sequences involving Markov and hierarchical clustering (Saunders et al. 2012), layering of taxonomic information, in planta upregulation data, and measures of selection (Sperschneider et al. 2014) are being used in attempts to identify pathogen 'Achilles heels' (Laugé et al. 1998) or 'core' effectors (Cooke et al. 2012; Dangl et al. 2013) as a means of rapidly identifying particular $R$ genes activated by those effectors to speed deployment (Vleeshouwers and Oliver [2014] described this strategy in breeding of potato against late blight caused by Phytophthora infestans). Further consideration needs to be given to interactions among different $R$ genes, and in the case of hosts, such as wheat, with APR genes, potential interactions between $R$ and APR genes. Some $R$ genes act additively (Roelfs 1987 ), as do some $R$ gene-APR gene combinations (Ellis et al. 2014). Utilizing the potential benefits of such interactions raises another level of complexity.

While strategies based around NBS-LRR genes undoubtedly have potential to confer greater resistance longevity in particular crop-pathogen combinations, they are not universally applicable. In particular, in many host-pathogen interactions (e.g., those involving hemibiotrophs or necrotrophic fungi), mechanisms of resistance are not well-understood and the number of known $R$ genes is limited. To date, the genetically based resistance deployed to assist control in such pathosystems has largely resulted from breeding for quantitative traits that affect pathogen aggressiveness (Lannou 2012; Thrall and Burdon 2003) or change host architectural structure or timing of critical growth stages (Andrivon et al. 2013). The latter types of traits, for example, the erectness of flag leaves (reducing periods of wetness) (Joshi and Chand 2002) or the timing of flowering (e.g., the success of 'Federation' in Australia at the beginning of the 20th century) can fundamentally alter the spatiotemporal dynamics of the interaction. For such quantitative traits, genomic and molecular technologies are already revolutionizing breeding with whole-genome selection approaches, potentially leading to more rapid genetic gain (Poland and Rife 2012; Varshney et al. 2014).

\section{NOVEL WAYS OF EXPLOITING HOST-PATHOGEN RECOGNITION SIGNALS}

Developmental constraints. A potentially powerful way of challenging pathogens is to engineer resistance genes that target essential 'housekeeping' molecules with critical roles in pathogen growth and survival. Such pathogen-associated molecular patterns (PAMPs) (e.g., bacterial flagellin, fungal chitin, elongation factor $\mathrm{Tu}$, and peptidoglycan [Michelmore et al. 2013]) are typically evolutionarily conserved. Hosts have evolved pattern recognition receptors (PRRs) that function as resistance genes by detecting PAMPs and initiating an immune response (Michelmore et al. 2013). While most hosts are resistant to most potential pathogens, successful pathogens are able to suppress PRR-based resistance using infectivity factors that suppress PAMP perception, signaling, and defense responses in host plants (Boller and $\mathrm{He} 2009$ ). Targeted engineering approaches have yet to deliver outcomes in the field, but model systems show the potential of this approach. Thus, transferring the Arabidopsis PRR gene EF-Tu (EFR) into Nicotiana benthamiana or Solanum lycospersicum (tomato) confers resistance on plants previously susceptible to a wide range of bacterial pathogens (Lacombe et al. 2010). This gene recognizes the bacterial translation elongation factor EF-Tu, an essential factor for protein synthesis that cannot be simply deleted or modified. More recently, the same PRR has been transferred into wheat, in which it confers resistance to Pseudomonas syringae (Schoonbeek et al. 2015), while the rice PRR XA21 confers resistance to Xanthomonas campestris when expressed in banana (Tripathi et al. 2014). Identification of PRRs through genomics and transfer into crop plants that lack an orthologous receptor could provide new sources of resistance to established pathogen species (Burdon et al. 2014; Dangl et al. 2013), but whether such engineering efforts will confer durable resistance remains to be seen and will likely depend on the complexity of the pathways required to circumvent the PRR and the ability of pathogens to acquire new infectivity factors via horizontal gene transfer.

Nonhost resistance. The frequent observation that most plant species are host to only a very limited range of pathogens has generated considerable interest in the concept of nonhost resistance and posed questions as to its genetic basis and whether it could be used to provide sources of durable resistance for a range of crops. While many intriguing results have been obtained (Ayliffe et al. 2011; Lipka et al. 2010; Mellersh and Heath 2003; Shafiei et al. 2007), the study of nonhost resistance and its potential practical value is still in its infancy (Bettgenhaeuser et al. 2014). In practice, delimiting the host range of a pathogen is complicated by the quantitative nature of responses in the transition from nonhost to host. In essence, detailed studies show a continuum of infection outcomes, ranging from basic incompatibility in which penetration fails to occur through increasing stages of interaction (leaf entry but no haustorial development, mycelia growth but no sporulation, to various manifestations of reproduction [Bettgenhaeuser et al. 2014]). Such observations are consistent with the concept that nonhost resistance mechanisms are layered (Thordal-Christensen 2003) and raise significant issues about the practicality of using such resistance routinely in an agronomic setting, because of the genetic complexity involved in achieving useful levels of resistance (Bettgenhaeuser et al. 2014). Furthermore, broader questions have been raised about the consequences for the donor species if the effectiveness of nonhost resistance transferred to recipient species erodes under pressures exerted by the targeted pathogen.

Resistance deployment strategies shaped by evolutionary considerations. In order to fit into Western agricultural settings dominated by large-scale extensive production of a uniform crop, 
most genetic-based strategies to disease control are heavily influenced by a strong technological approach. While efficacy in providing protection is clearly an important issue, choice around the most appropriate strategy to use has largely been driven by utility, ease of manipulation in breeding programs, and perceived market expectations concerning product uniformity. Several authors have recently alluded to the importance of considering how best to use genetically based resistance to effect disease control in cereals. Ellis and colleagues (2014) favor the use of all possible genetic tools (both $R$ and APR genes) in generating effective resistance, while Wulff and Moscou (2014) advocate for better understanding of which $R$ genes to clone and how to effectively combine these. From an evolutionary perspective, both views suggest an approach that is little changed from current practice. While showing increasing sophistication, they would still impose strong directional selection on the pathogen. An alternative approach recognizes the value of cloning and characterizing individual genes and their interactions within the genome but moves beyond what is essentially continuation of a 'brute force' approach to one that explicitly integrates evolutionary considerations (McDonald and Linde 2002a, b). It uses resistances to generate a series of different selective pressures that, when summed together, constitute forces of fluctuating directional selection on the pathogen that reduce the probability of the appearance of a single genotype with high fitness on all host types (Burdon et al. 2014; Zhan et al. 2014, 2015).

Basic characteristics such as inherent mutation and recombination rates are important determinants of pathogen evolutionary potential (Barrett et al. 2008; McDonald and Linde 2002a). However, it is the outcomes of dispersal that ultimately determine the frequency with which actual mutational change is observed in a pathogen population. Spores that disperse successfully beyond the confines of their parental host (allo-infection [Robinson 1976]) and land on genetically different individuals of the same species (e.g., a different variety in an adjacent field) are immediately 'challenged' as to their ability to avoid detection by that plant's defense screen. Failure to circumvent those defenses results in death (mortality selection focused on infectivity) or drastically reduced reproduction (incomplete resistance, fecundity selection focused on aggressiveness). Substantial evidence has accumulated indicating that mutation to infectivity, in some cases, carries a reproductive fitness cost, expressed as reduced propagule production. Such trade-offs between infectivity and aggressiveness may not be apparent in comparisons of pathogen isolates differing by only one infectivity gene, although such costs are potentially significant across the broader spectrum of infectivity present in many pathogen populations (e.g., Melampsora lini [Thrall and Burdon 2003], Puccinia coronata [Bruns et al. 2014]). Such trade-offs play an important role in generating local adaptation by impeding the emergence of individual pathotypes that possess infectivity with respect to a large number of $R$ genes.

In contrast to allo-infection, auto-infection (Robinson 1976)dispersal back to the same host individual (or, in a selective sense, to other genetically identical host individuals, as would be typical in extensive cropping systems) - reduces the probability that a mutation for broader infectivity will survive as that mutant would have no selective advantage (and possibly even negative fitness) over its nonmutant siblings, given that the successful parental infection already possesses an infectivity profile appropriate to that host. In such circumstances, the mutant is just one among many spores competing to establish and reproduce in an environment in which selection pressures are focused on traits likely to increase aggressiveness (Abang et al. 2006; van den Berg et al. 2013; Wang et al. 2008).

Variation in the diversity and spatial distribution of host populations have been shown to have significant impact on the occurrence and severity of disease and the evolutionary trajectory of pathogens at a range of scales (Fabre et al. 2015). At the landscape level, the dynamic nature of the interface between agricultural fields and surrounding vegetation and how variation in the ratio of crop to noncrop areas may influence the way pathogens and their hosts interact has been the subject of simulation modeling (Papaix et al. 2015). In situations in which a pathogen grows on both a crop and a wild host, as the relative area devoted to noncrop use increases, larger pathogen populations develop on wild hosts, thereby facilitating the emergence of novel pathotypes. However, interactions between the proportion of crop use within the landscape and pathogen life history features simultaneously increased pathogen adaptation to its noncrop hosts, thereby reducing the chance of the emergence of a novel crop-infecting pathotype.

At a similar spatial scale, diversity in crop species and pure-line plantings of different varieties of a single species have a tendency to reduce disease (Papaïx et al. 2011). Data for similar effects within fields, through either intercropping or the deployment of mixtures of different varieties or near-isogenic lines, is even stronger (Boudreau 2013; Finckh and Wolfe 2006; Mundt 2002; Schoeny et al. 2010). Essentially, all these studies support the view that host diversity and how it is deployed has the potential to be a powerful factor affecting pathogen epidemiology and evolution. A key issue is whether this knowledge can be practically utilized to drive disease severity to subeconomic levels in the short term and reduce evolutionary directional selection pressures on the pathogen population while simultaneously being cost-effective for deployment by farmers.

The use of varietal mixtures, multilines, or populations has had enduring appeal because of perceived theoretical benefits (reduced inoculum, slower epidemic development, intermediate pathogen infectivity) and a belief that such benefits translate into practical reductions in disease severity and increased yield. The majority of small plot and similar assessments have demonstrated significant reductions in disease severity (Finckh and Wolfe 2006; Mundt 2002; Wolfe 1985) with varying but, nearly always, zero to positive yield benefits (Burdon 1987; Finckh et al. 2000). Broad-scale assessments of the effects of in-crop diversification strategies have been infrequent, but their use in significant rice-growing areas in Yunnan, China was linked to a $94 \%$ reduction in the severity of rice blast disease occurring on susceptible glutinous rice varieties (and a concomitant yield increase of $89 \%$ ) when grown in approximately 20:80 mixtures with resistant hybrid varieties (Zhu et al. 2000). Perhaps more telling are the significant changes that occur in the infectivity and aggressiveness of pathogen populations in such situations. Where detailed studies have been executed, pathogen population structures have moved toward greater domination by pathotypes with intermediate levels of infectivity and high adaptation (increased aggressiveness) on specific host elements of the mixture (Chin and Wolfe 1984; Dileone and Mundt 1994; Kolmer 1995). However, the longer-term trajectory of such evolutionary changes is unknown (Mundt 2002).

A point of concern regarding the use of varietal mixtures has been the potential for diversity in a range of agronomy characters (e.g., maturity date, quality) that could present harvesting and marketing issues. While it is clear that major differences in maturity date would present significant harvesting difficulties, concerns around quality reflect either legitimate specific use concerns (e.g., malting in barley) or a perceived but, often, unnecessary need for purity in grains that are typically mixed at receiving points or by millers during manufacturing processes. Gene-editing approaches using systems such as CRISPR/Cas9 (Belhaj et al. 2015) offer the possibility of constructing truly isogenic lines in which the only differences between lines within the mixture are related to disease resistance, thereby negating these concerns. At the same time, though, unquestioning use of this approach might make the variety vulnerable to other biotic stresses to which the specific genetic background involved conferred little protection (for instance, hypersusceptibility of corn based on Texas cytoplasm male sterility to Helminthosporium maydis and Phyllosticta maydis [Ullstrup 1972]). A partial solution to this possibility lies in gene-editing approaches 
involving the insertion of complex gene cassettes addressing several pathogens (McDonald 2014).

Given the above considerations, there is currently a great need to make effective use of the opportunity afforded by recent advances in our ability to generate diverse combinations of resistance genes. By methodically combining resistance of the same or different types $(R$ genes, both those expressed as immune and incomplete infection types, APR genes, QTL) within the same host individuals or in different individuals in the same host population, it is conceptually possible to generate fluctuating direction selection that keeps the pathogen constantly 'off-balance.' Early, simple global dispersal models suggested that particular combinations of $R$ genes were better able to affect pathogen evolution than others (Lannou and Mundt 1997; Marshall and Weir 1985). However, the combinations envisaged at that time were very limited compared with what is now possible. More recent mathematical and simulation models

\section{BOX 1. EPIDEMIOLOGICAL VERSUS EVOLUTIONARY DISEASE CONTROL}

Measures of disease control: Disease control in agricultural systems generally focuses on short-term epidemiological outcomes and aims to reduce disease severity on a crop or in an agricultural region over a given period of time. Resistance durability is another aspect of disease control, evaluated by different phases of the demo-genetic dynamics of pathogen populations (van den Bosch and Gilligan 2003), e.g., time to establishment and invasion of infective genotypes, time during which a resistance $(R)$ gene still effectively provides protection, time during which the resistant variety still contributes to lowering disease overall. In the case of quantitative resistance, resistance durability is replaced by the speed at which resistance erodes, i.e., the speed at which the pathogen population adapts to a resistant variety. Finally, expected evolutionary outcomes, e.g., the level of specialization on each crop variety, the genetic composition of the pathogen population, and its impact on expected disease severity, define disease control over longer time scales. As we illustrate below, consideration of these different dimensions of disease control highlights complexities associated with provision of comprehensive solutions when designing deployment strategies for crop disease resistance (Fig. 1A and B).

Optimizing short-term epidemiological control: Epidemiological control based on mixing susceptible and resistant plant genotypes in the same field has largely been studied in the literature, and this idea has been extended more recently to the landscape level. Basically, diversification of $R$ genes reduces disease transmission by modifying the alloinfection/autoinfection ratio. In that sense, the efficacy of such deployment strategies depends on the composition of the mixture and the spatial arrangement of each component, with a crucial impact of inoculum position and pathogen dispersal (Mundt 2002). Obviously, epidemiological disease control increases with the cropping ratio of the resistant varieties. In the case of major $R$ genes or strong quantitative resistances, decreasing the spatial aggregation among varieties is always optimal to lower the disease severity both at field and landscape levels (Skelsey et al. 2010), because resistant varieties reduce connectivity among susceptible patches without being impacted much by the pathogen. However, such strategies could be suboptimal for weaker quantitative resistances. Indeed, epidemics typically proceed on the resistant variety by spill-over from the most competent host, potentially leading to heavier losses on resistant genotypes with a weak quantitative resistance that are not compensated by sufficient gains on susceptible varieties (Papaï et al. 2014).

Optimizing resistance durability: Durability of $R$ genes is commonly preserved by using a low cropping ratio of a resistant variety (Pink and Puddephat 1999) to reduce the selection pressure caused by new resistant genes and avoid rapid selection of infective pathogen genotypes (boom and bust cycles). In addition, maintaining small homogeneous regions of resistant varieties (keeping the cropping ratio low) could further increase the durability of qualitative resistances. Indeed, more aggregated patterns lead to a more concentrated interface between susceptible and resistant varieties, which limits immigration of new infectivity and facilitates the deployment of other control strategies (e.g., use of chemicals) to keep the pathogen population small and reduce its evolutionary potential (Zhan et al. 2015). However, such strategies are not conducive to short-term epidemiological control, since the cropping ratio between resistant and susceptible varieties is too low to provide a protective advantage for the susceptible variety.

Optimizing long-term evolutionary control: While short-term epidemiological control requires broadscale deployment (and low spatial aggregation) of resistant varieties, resistance durability depends on a low cropping ratio with high spatial aggregation of resistant varieties. However, long-term evolutionary control of plant diseases is predicted to be optimal with the highest level of $R$ gene diversity and could, thus, conflict with other dimensions of disease control. The predicted efficiency of long-term control strategies based on diversification of major $R$ genes is based on evidence that mutations to infectivity come with a fitness cost for the pathogen that can prevent the emergence of highly infective pathogen superraces (Thrall and Burdon 2003). Such trade-offs among pathogen life-history traits can also constrain the evolution of increased aggressiveness (Lannou 2012), suggesting that diversification among quantitative resistances should also be efficient for long-term disease control. Spatial aspects are also important to consider when designing solutions based on evolutionary principles. Indeed, theory predicts that large homogeneous areas facilitate pathogen adaptation by increasing both the speed of resistance erosion and the aggressiveness of some pathogen races to particular crop varieties (Papaïx et al. 2013).

Temporal dimension of disease control: The discussion above focused on the spatial component of $R$-gene deployment, but the temporal dimension is also important to keep pathogen populations maladapted to crops by moving the direction of selection across time (Zhan et al. 2015). For example, the reversibility of susceptibility was observed in the case of wheat leaf rust at the scale of France, with a wheat cultivar (Soissons) extremely susceptible to Puccinia triticina becoming more and more resistant because of a shift in aggressiveness of the pathogen population to newly released wheat cultivars (Fig. 1C) (Papaïx et al. 2011). In addition, seasonality could be particularly drastic in the agricultural landscape, with some periods with virtually no hosts for annual crops, which forces pathogens to develop specific survival forms or to switch on unmanaged plants (volunteers, wild plants) in which the biotic and physical environment is less stable. However, little information is available on the role of the noncropping season in determining year-to-year genetic structure of pathogen populations.

The considerations discussed here make clear that to increase the effectiveness of managing diseases via deployment of genetically resistant crop varieties, comprehensive demo-genetic models are needed to explore the consequences of different spatio-temporal strategies. However, such modeling efforts must be integrated with large-scale experiments for calibration and parameter estimation. Finally, adoption of adaptive management strategies will also require ongoing surveys of pathogen populations to assess the efficacy of different deployment options. 
have extensively investigated the effects of increased within-crop diversity of $R$ genes. Such models increasingly incorporate added levels of ecological realism (spatially explicit dispersal, fitness costs associated with infectivity) and generally predict that increased $R$-gene diversity will lead to pathogenically more diverse (i.e., more different pathotypes) pathogen populations carrying, on average, fewer infectivity genes (Lannou 2001; Lannou and Mundt 1997) but with varying levels of aggressiveness (Lannou 2001; Marshall et al. 2009).

The spatial distribution of resistances within host populations is a critical factor in driving evolutionary outcomes. Patchy distributions of resistances may lead to pathogen diversification and local adaptation that reduces effectiveness of the deployment strategy relative to more random patterns of different monogenic resistances in a mixture (Sapoukhina et al. 2009). In an important parallel step, Bourget and colleagues (2015) developed an individualbased stochastic model to explore options for the deployment of quantitative resistance. The model involves two components of quantitative resistance (colonizing capacity (ability to actually infect) and reproductive rate (infection efficiency, latent period, spore production) and shows how these two components may work together synergistically to influence rates of pathogen evolution. The study also underlines the lack of information available regarding processes involved in progressive adaptation by pathogens to quantitative resistance. A spatially explicit gene-for-gene model that included major resistance alleles conferring either complete or incomplete (= partial) resistance to specific pathotypes was recently developed (A. Nemri, J. J. Burdon, M. E. Hochberg, and $\mathrm{P}$. H. Thrall unpublished data). It was found that these two types of resistance with their different selective impacts on the pathogen population acted synergistically when deployed among different host individuals in the crop. This led to a reduction in the intensity of disease epidemics as well as slower rates of pathogen evolution toward increased infectivity.

Consideration of the multiple ways in which different resistance types could be deployed in crops and the relative efficacy of various deployment strategies with regard to reducing the incidence and severity of epidemics and the long-term durability of resistance relative to existing and future proposed pyramiding or genestacking strategies is still very much in its infancy. Importantly, empirical assessments of different strategies are generally lacking. However, there are many reasons to believe that, by subjecting pathogens to shifting selective forces, their epidemiological and evolutionary potential would be greatly diminished. It should be noted, in this regard, that single, static approaches to disease management will not be sustainable in the long run, regardless of the short-term effectiveness of the approach, due to the constant evolution of pathogens. Adaptive management schemes are needed that use all possible combinations of available approaches to provide crops with an evolutionary advantage. Given the considerable foodrelated challenges the world currently faces, we would be remiss if all possible approaches to controlling the epidemiological and evolutionary trajectories of pathogens were not systematically explored (Thrall et al. 2011).

\section{CONCLUSIONS AND IMPORTANT UNRESOLVED QUESTIONS}

Successful implementation of durable resistance strategies relies on a thorough understanding of the genetic nature of host-pathogen interactions and how these play out through changing patterns of infectivity and aggressiveness under different environmental conditions. While genomic and molecular technologies may eventually allow the construction of host defenses that are insurmountable to target pathogens, for technical, societal, and regulatory reasons, the construction and field deployment of such 'super' varieties in many crops is likely to be a decade or multiple decades away (Dangl et al. 2013). However, in the meantime, we are currently unable to predict which genetic deployment strategies will be optimal in managing disease, both from an epidemiological as well as an evolutionary perspective (Box 1; Fig. 1). Indeed, our knowledge about many of the important temporal components of the evolutionary interplay between host and pathogen is still rudimentary. We may speculate as to why some resistance genes appear to last longer than others or why some 'durable' quantitative resistance erodes more rapidly than others, but in most cases, we lack predictive capacity.

The challenge we face is to understand the factors driving variation in the longevity of resistances and how best to shape epidemiological and evolutionarily based deployment strategies to simultaneously reduce short-term epidemic development as well as the probability of longer-term evolutionary change in the pathogen. Successful execution of this approach requires integrated theoretical and empirical (particularly field-based) studies. Agriculturally realistic simulation models form a key element of this approach but need to be informed by detailed knowledge of pathogen biology and life history. Greater knowledge of (i) fitness costs associated with mutations affecting pathogen infectivity or aggressiveness,; (ii) the genetic and physiological basis of such costs, (iii) their interplay with the biotic and abiotic environment, (iv) the degree to which selection for aggressiveness is affected by host cultivar diversity, and (v) whether increases in aggressiveness occur linearly or follow some sort of sigmoidal function are all critical to predicting the evolutionary trajectories of plant pathogens and, hence, the durability of control (Burdon et al. 2014; Lannou 2012; Leach et al. 2001; Zhan and McDonald 2013). Model predictions need to be assessed in the real world, where the full effects of environmental variation can play out. Such integrated approaches also need to account for significant differences in the life-history attributes of biotrophic and necrotrophic pathogens (noting that biotrophic interactions have received the majority of research interest). These differences can change the size and dynamics of populations through time as well as the extent of potential evolutionary conflicts (Abang et al. 2006; Barrett et al. 2008, 2011; Sommerhalder et al. 2011; Thrall and Burdon 2004).

Traditionally growers and pathologists have largely focused consideration of the epidemiology and control of diseases on individual crops in specific locations. However, increasingly, disease control in crops is being seen in a much broader context involving whole farm or even a catchment or regional level focus (Fabre et al. 2012; Burdon et al. 2014; McDonald 2014; Zhan et al. 2015). This systems approach is being driven by a broad range of factors including (i) increased societal expectations regarding the sustainability of farming practices and the broader biotic environment in which they are embedded, (ii) recognition that many crop pathogens survive the off-season on crop volunteers, weeds, or wild plants in adjacent nontilled areas, (iii) recognition that the application of simple 'technological fixes' rarely solves problems in the longterm, (iv) severe production cost squeezes, (v) long distance movement of pathogens by commercial or other human activities, and (vi) opportunities that spatial technologies and automation can bring to precision tailoring of farming interventions.

In devising disease management strategies for the future, we have a responsibility to consider all economically viable disease control options across the diversity of arable species used in the world. While the broad-scale industrialized agriculture practiced in the developed world is an important part of the food production and security equation of the future, that paradigm is not responsible for the majority of the world's arable agricultural production. Rather, it is production from small hectare or smaller sized holdings in the developing world that, summed together, provides the bulk of yield for many crops. Growers in those situations rarely have the financial resources for expensive inputs (certified seed, GM seed, hybrids, pesticides), yet effective disease reduction would be enormously beneficial. For example, in the Yunnan province of China, although more than 600,000 hectares are annually cultivated for potato production, average farm plots are typically less than a hectare 
A Typical dynamics of disease severity and pathogen evolution in a landscape composed of a susceptible and newly released resistant crop variety

(a)

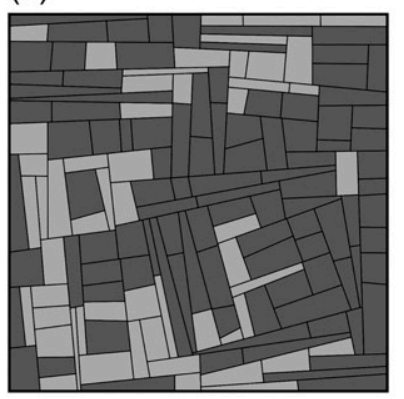

$\star$ Major R gene breakdown (b)

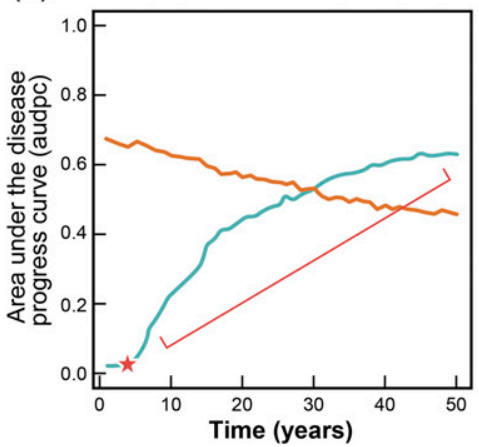

Erosion of quantitative resistance (c)

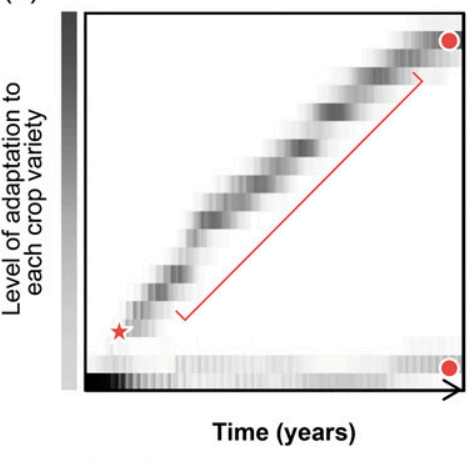

B Contrasted deployment strategies of a newly released resistant crop variety and expected effects on disease control

(d)

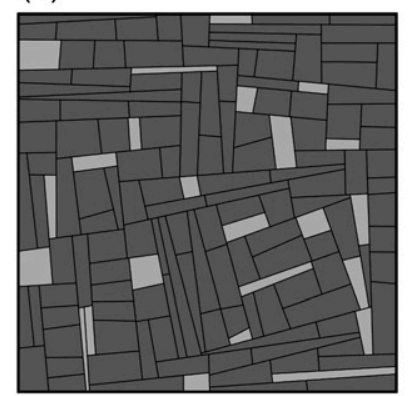

(e)

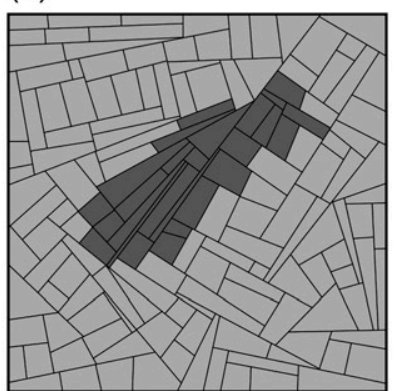

(f)

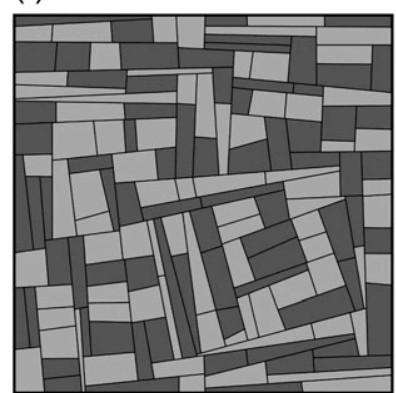

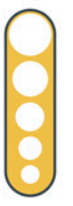

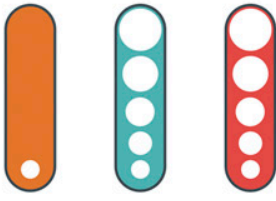

very high
high
fair
low
very low
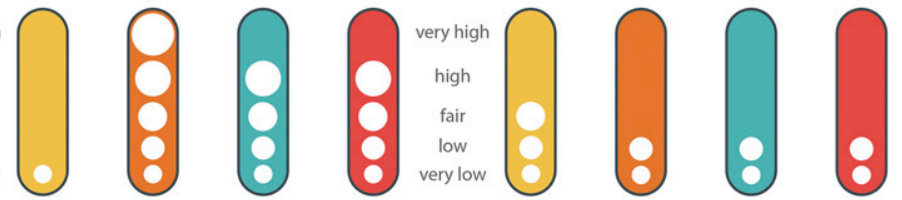

OEpidemiological control OMajor gene durability OSpeed of erosion $\bigcirc$ Level of pathogen adaptation

\section{The case of a susceptible crop variety becoming resistant again}

(g)

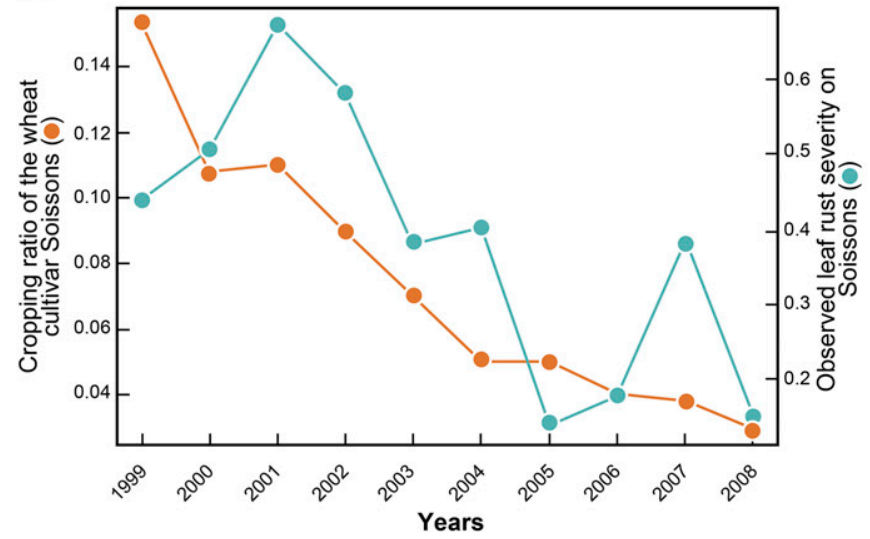

(h)

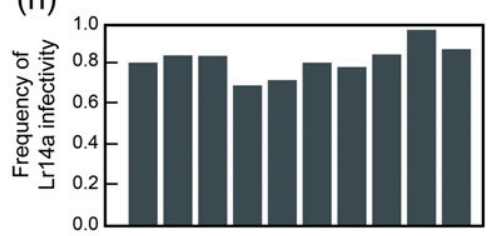

(i)

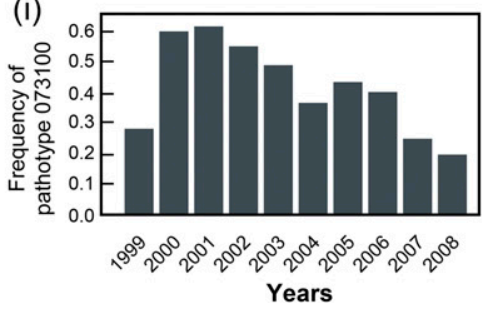

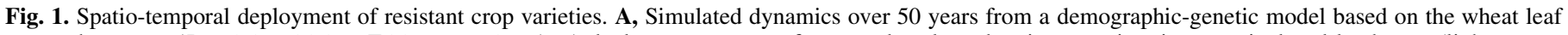

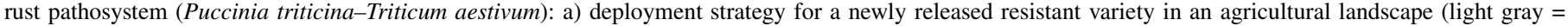

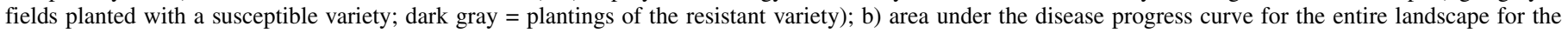

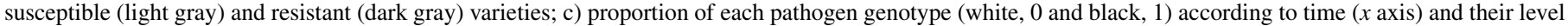

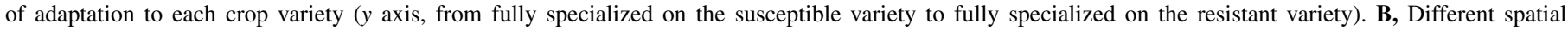

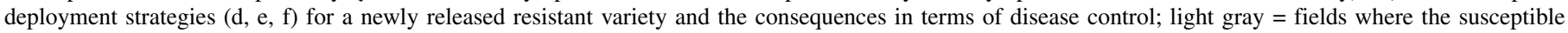

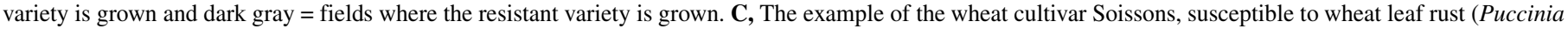

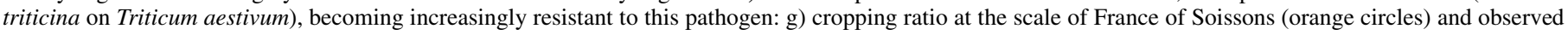

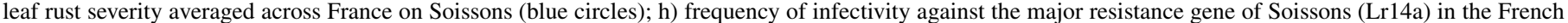
Puccinia triticina population, showing that qualitative resistance is not responsible for the decrease in susceptibility of Soissons (Papaix et al. 2011). 
in size. Average yields fall short of the area's yield potential by a factor of 10, primarily due to the dual effects of early drought and midseason late blight (Phytophthora infestans) epidemics (Q. J. Sui personal communication). Reducing disease loads for these and countless other growers in similar situations requires low-cost technologies coupled with effective management strategies. That management strategies can have a substantial impact on yield in disease-prone environments was clearly shown in rice (Zhu et al. 2000). By coupling the power and capability of modern genomic and molecular approaches to identify and manipulate resistance traits with sound evolutionary principles guiding spatio-temporal deployment, significant gains can be achieved for farming systems world wide.

\section{ACKNOWLEDGMENTS}

J. Zhan was partially supported by Modern Agricultural Industry and Technology System of China grant number CARS-10, National Natural Science Foundation of China for Mainland-Taiwan Collaboration grant number U1405213, and Ministry of Science and Technology of China "973" Initiative grant number 2014CB160315; L. G. Barrett and P. H. Thrall were partially supported by the Grains Research \& Development Corporation of Australia.

\section{LITERATURE CITED}

Abang, M., Baum, M., Grando, S., Ceccarelli, S., Linde, C. C., Yahyaoui, A., Zhan, J., and McDonald, B. A. 2006. Differential selection on Rhynchosporium secalis during parasitic and saprophytic phases in the barley scald disease cycle. Phytopathology 96:1214-1222.

Andrivon, D., Giorgetti, C., Baranger, A., Calonnec, A., Cartolaro, P., Faivre, R., Guyader, S., Lauri, P. E., Lescourret, F., Parisi, L., Ney, B., Tivoli, B., and Sache, I. 2013. Defining and designing plant architectural ideotypes to control epidemics? Eur. J. Plant Pathol. 135:611-617.

Andrivon, D., Pilet, F., Montarry, J., Hafidi, M., Corbiere, R., Achbani, E. H., Pelle, R., and Ellisseche, D. 2007. Adaptation of Phytophthora infestans to partial resistance in potato: Evidence from French and Moroccan populations. Phytopathology 97:338-343.

Ayliffe, M., Devilla, R., Mago, R., White, R., Talbot, M., Pryor, A., and Leung, H. 2011. Nonhost resistance of rice to rust pathogens. Mol. Plant-Microbe Interact. 24:1143-1155.

Barrett, L. G., Bell, T., Dwyer, G., and Bergelson, J. 2011. Cheating, trade-offs and the evolution of aggressiveness in a natural pathogen population. Ecol. Lett. 14:1149-1157.

Barrett, L. G., Thrall, P. H., Burdon, J. J., and Linde, C. C. 2008. Life history determines genetic structure and evolutionary potential of populations. Trends Ecol. Evol. 23:678-685.

Belhaj, K., Chaparro-Garcia, A., Kamoun, S., Patron, N. J., and Nelrasov, V. 2015. Editing plant genomes with CRISPR/Cas9. Curr. Opin. Biotechnol. 32:76-84.

Bettgenhaeuser, J., Gilbert, B., Ayliffe, M., and Moscou, M. J. 2014. Nonhost resistance to rust pathogens - a continuation of continua. Front. Plant Sci. 5: 664.

Boevink, P. C., McLellan, H., Gilroy, E. M., Naqvi, S., He, Q., Yang, L. N., Wang, X. D., Turnbull, D., Armstrong, M. R., Tian, Z. D., and Birch, P. R. J. 2016. Oomycetes seek help from the plant: Phytophthora infestans effectors target host susceptibility factors. Mol. Plant 9:636-638.

Boller, T., and He, S. Y. 2009. Innate immunity in plants: An arms race between pattern recognition receptors in plants and effectors in microbial pathogens. Science 324:742-744.

Boudreau, M. A. 2013. Diseases in intercropping systems. Annu. Rev. Phytopathol. 51:499-519.

Bourget, R., Chaumont, L., Durel, C.-E., and Sapoukhina, N. 2015. Sustainable deployment of QTLs conferring quantitative resistance to crops: First lessons from a stochastic model. New Phytol. 206:1163-1171.

Brown, J. K. M. 2015. Durable resistance of crops to disease: A Darwinian perspective. Annu. Rev. Phytopathol. 53:513-539.

Brown, J. K. M., and Hovmøller, M. S. 2002. Epidemiology-Aerial dispersal of pathogens on the global and continental scales and its impact on plant disease. Science 297:537-541.

Bruns, E., Carson, M., and May, G. 2012. Pathogen and host genotype differently affect pathogen fitness through their effects on different life-history stages. BMC Evol. Biol. 12:135.

Bruns, E., Carson, M., and May, G. 2014. The jack of all trades is master of none: A broader genotype range in a plant pathogen comes at a cost of delayed reproduction and smaller infections. Evolution 68:2453-2466.
Burdon, J. J. 1987. Diseases and Plant Population Biology. Cambridge University Press, Cambridge, 208 pp.

Burdon, J. J., Barrett, L. G., Rebetzke, G., and Thrall, P. H. 2014. Guiding deployment of resistance in cereals using evolutionary principles. Evol. Appl. 7:609-624.

Burdon, J. J., Marshall, D. R., and Luig, N. H. 1981. Isozyme analysis indicates that a virulent cereal rust pathogen is a somatic hybrid. Nature 293: 565-566.

Burdon, J. J., and Thrall, P. H. 2009. Coevolution of plants and their pathogens in natural habitats. Science 324:755-756.

Burdon, J. J., and Thrall, P. H. 2014. What have we learned from studies of wild plant-pathogen associations?-The dynamic interplay of time, space and life-history. Eur. J. Plant Pathol. 138:417-429.

Caffier, V., Lasserre-Zuber, P., Giraud, M., Lascostes, M., Stievenard, R., Lemarquand, A., van de Weg, E., Expert, P., Denancé, C., Didelot, F., Le Cam, B., and Durel, C. E. 2014. Erosion of quantitative host resistance in the apple $\times$ Venturia inaequalis pathosystems. Infect. Genet. Evol. 27: 481-489.

Chin, K. M., and Wolfe, M. S. 1984. Selection on Erysiphe graminis in pure and mixed stands of barley. Plant Pathol. 33:535-546.

Cooke, D. E., Cano, L. M., Raffaele, S., Cooke, L. R., Etherington, G., Deahl, K. L., Farrer, R. A., Gilroy, E. M., Goss, E. M., Grünwald, N. J., and 13 others. 2012. Genome analysis of an aggressive and invasive lineage of the Irish potato famine pathogen. PLoS Pathog 8:e1002940.

Cowger, C., and Mundt, C. C. 2002. Aggressiveness of Mycosphaerella graminicola isolates from susceptible and partially resistant wheat cultivars. Phytopathology 92:624-630.

Dangl, J. L., Horvath, D. M., and Staskawicz, B. J. 2013. Pivoting the plant immune system from dissection to deployment. Science 341:746-751.

de Jonge, R., Bolton, M. D., Kombrink, A., van den Berg, G. C. M., Yadeta, K. A., and Thomma, B. P. H. J. 2013. Extensive chromosomal reshuffling drives evolution of virulence in an asexual pathogen. Genome Res. 23: 1271-1282.

Delmotte, F., Mestre, P., Schneider, C., Kassemeyer, H. H., Kozma, P., Richart-Cervera, S., Rouxel, M., and Delière, L. 2014. Rapid and multiregional adaptation to host partial resistance in a plant pathogenic oomycete: Evidence from European populations of Plasmopara viticola, the causal agent of grapevine downy mildew. Infect. Genet. Evol. 27:500-508.

Dileone, J. A., and Mundt, C. C. 1994. Effect of wheat cultivar mixtures on populations of Puccinia striiformis races. Plant Pathol. 43:917-930.

Dodds, P. N., Lawrence, G. J., Catanzariti, A. M., The, T., Wang, C. I. A., Ayliffe, M. A., Kobe, B., and Ellis, J. G. 2006. Direct protein interaction underlies gene-for-gene specificity and coevolution of the flax resistance genes and flax rust avirulence genes. Proc. Natl. Acad. Sci. U.S.A. 103: 8888-8893.

Dodds, P. N., and Rathjen, J. P. 2010. Plant immunity: Towards an integrated view of plant-pathogen interactions. Nat. Rev. Genet. 11:539-548.

Ellis, J. G., Lagudah, E. S., Spielmeyer, W., and Dodds, P. N. 2014. The past, present and future of breeding rust resistant wheat. Front. Plant Sci. 5:641.

Fabre, F., Rousseau, E., Mailleret, L., and Moury, B. 2012. Durable strategies to deploy plant resistance in agricultural landscapes. New Phytol. 193: 1064-1075.

Fabre, F., Rousseau, E., Mailleret, L., and Moury, B. 2015. Epidemiological and evolutionary management of plant resistance: Optimizing the deployment of cultivar mixtures in time and space in agricultural landscapes. Evol. Appl. 8:919-932.

Figueroa, M., Upadhyaya, N. M., Sperschneider, J., Park, R. F., Szabo, L. J., Steffenson, B., Ellis, J. G., and Dodds, P. N. 2016. Changing the game: Using integrative genomics to probe virulence mechanisms of the stem rust pathogen Puccinia graminis f.sp. tritici. Front. Plant Sci. 7:205.

Finckh, M. R., Gacek, E. S., Goyeau, H., Lannou, C., Merz, U., Mundt, C. C., Munk, L., Nadziak, J., Newton, A. C., de Vallavielle-Pope, C., and Wolfe, M. S. 2000. Cereal variety and species mixtures in practice, with emphasis on disease resistance. Agronomie 20:813-837.

Finckh, M. R., and Wolfe, M. S. 2006. Diversification strategies. Pages 269-307 in: The Epidemiology of Plant Disease. B. M. Cooke, D. G. Jones, and B. Kaye, eds. Springer, Berlin.

Friesen, T. L., Stukenbrock, E. H., Liu, Z., Meinhardt, S., Ling, H., Faris, J. D., Rasmussen, J. B., Solomon, P. S., McDonald, B. A., and Oliver, R. P. 2006. Emergence of a new disease as a result of interspecific virulence gene transfer. Nat. Genet. 38:953-956.

Goss, E. M. 2015. Genome-enabled analysis of plant-pathogen migration. Annu. Rev. Phytopathol. 53:121-135.

Johnson, R., and Taylor, A. J. 1976. Spore yield of pathogens in investigations of the race-specificity of host resistance. Annu. Rev. Phytopathol. 14:97119.

Johnson, R. D., and Lewis, B. G. 1994. Variation in host range, systemic infection and epidemiology of Leptosphaeria maculans. Plant Pathol. 43: 269-277. 
Johnson, T. 1961. Man-guided evolution in plant rusts. Science 133:357-362. Joshi, A. K., and Chand, R. 2002. Variation and inheritance of leaf angle, and its association with spot blotch (Bipolaris sorokiniana) severity in wheat (Triticum aestivum). Euphytica 124:283-291.

Kolmer, J. A. 1995. Selection of Puccinia recondita f.sp. tritici virulence phenotypes in three multilines of Thatcher wheat lines near isogenic for leaf rust resistance genes. Can. J. Bot. 73:1081-1088.

Krattinger, S. G., Lagudah, E. S., Spielmeyer, W., Singh, R. P., Huerta-Espino, J., McFadden, H., Bossolini, E., Selter, L. L., and Keller, B. 2009. A putative $\mathrm{ABC}$ transporter confers durable resistance to multiple fungal pathogens in wheat. Science 323:1360-1363.

Lacombe, S., Rougon-Cardoso, A., Sherwood, E., Peeters, N., Dahlbeck, D., van Esse, H. P., Smoker, M., Rallapalli, G., Thomma, B. P. H. J., Staskawicz, B., Jones, J. D. G., and Zipfel, C. 2010. Interfamily transfer of a plant pattern-recognition receptor confers broad-spectrum bacterial resistance. Nat. Biotechnol. 28:365-369.

Laine, A.-L., Burdon, J. J., Dodds, P. N., and Thrall, P. H. 2011. Spatial variation in disease resistance: From molecules to metapopulations. J. Ecol. 99:96-112.

Laine, A.-L., and Hanski, I. 2006. Large-scale spatial dynamics of a specialist plant pathogen in a fragmented landscape. J. Ecol. 94:217-226.

Lannou, C. 2001. Intrapathotype diversity for aggressiveness and pathogen evolution in cultivar mixtures. Phytopathology 91:500-510.

Lannou, C. 2012. Variation and selection of quantitative traits in plant pathogens. Annu. Rev. Phytopathol. 50:319-338.

Lannou, C., and Mundt, C. C. 1997. Evolution of a pathogen population in host mixtures: Rate of emergence of complex races. Theor. Appl. Genet. 94: 991-999.

Laugé, R., Joosten, M. H. A. J., Haanstra, J. P., Goodwin, P. H., Lindhout, P., and de Wit, P. J. G. M. 1998. Successful search for a resistance gene in tomato targeted against a virulence factor of a fungal pathogen. Proc. Natl. Acad. Sci. U.S.A. 95:9014-9018.

Lawrenson, T., Shorinola, O., Stacey, N., Li, C., Østergaard, L., Patron, N., Uauy, C., and Harwood, W. 2015. Induction of targeted, heritable mutations in barley and Brassica oleracea using RNA-guided Cas9 nuclease. Genome Biol. 16:258.

Leach, J. E., Vera-Cruz, J. C. M., Bai, F., and Leung, H. 2001. Pathogen fitness penalty as a predictor of durability of disease resistance genes. Annu. Rev. Phytopathol. 39:187-224.

Lebeda, A., Petrzelova, I., and Maryska, Z. 2008. Structure and variation in the wild-plant pathosystem: Lactuca serriola-Bremia lactucae. Eur. J. Plant Pathol. 122:127-146.

Li, J., Ding, J., Zhang, W., Zhang, Y. L., Tang, P., Chen, J.-Q., Tian, D. C., and Yang, S. H. 2010. Unique evolutionary pattern of numbers of gramineous NBS-LRR genes. Mol. Genet. Genomics 283:427-438.

Lipka, U., Fuchs, R., Kuhns, C., Petutschnig, E., and Lipka, V. 2010. Live and let die-Arabidopsis nonhost resistance to powdery mildews. Eur. J. Cell Biol. 89:194-199.

Lo Iacono, G., van den Bosch, F. N., and Paveley, N. 2012. The evolution of plant pathogens in response to host resistance: Factors affecting the gain from deployment of qualitative and quantitative resistance. J. Theor. Biol. 304:152-163.

Luig, N. H., and Watson, I. A. 1972. The role of wild and cultivated grasses in the hybridization of formae speciales of Puccinia graminis. Aust. J. Biol. Sci. 25:335-342.

Mago, R., Brown-Guedira, G., Dreisigacker, S., Breen, J., Lin, Y., Singh, R., Appels, R., Lagudah, E. S., Ellis, J., and Spielmeyer, W. 2011. An accurate DNA marker assay for stem rust resistance gene $\mathrm{Sr} 2$ in wheat. Theor. Appl. Genet. 122:735-744.

Marshall, B., Newton, A. C., and Zhan, J. 2009. Quantitative evolution of aggressiveness of powdery mildew under two-cultivar barley mixtures. Plant Pathol. 58:378-388.

Marshall, D. R., and Weir, B. S. 1985. Multiline varieties and disease control 5. The 'dirty crop' approach with complex mixtures of genotypes based on overlapping gene sets. Theor. Appl. Genet. 69:463-474.

Mboup, M., Bahri, B., Leconte, M., De Vallavieille-Pope, C., Kaltz, O., and Enjalbert, J. 2012. Genetic structure and local adaptation of European wheat yellow rust populations: The role of temperature-specific adaptation. Evol. Appl. 5:341-352.

McDonald, B. A. 2014. Using dynamic diversity to achieve durable disease resistance in agricultural ecosystems. Trop. Plant Pathol. 39:191-196.

McDonald, B. A., and Linde, C. 2002a. Pathogen population genetics, evolutionary potential, and durable resistance. Annu. Rev. Phytopathol. 40:349-379.

McDonald, B. A., and Linde, C. 2002b. The population genetics of plant pathogens and breeding strategies for durable resistance. Euphytica 124:163-180.

McIntosh, R. A., Wellings, C. R., and Park, R. F. 1995. Wheat rusts: An atlas of resistance genes. CSIRO Publications, Melbourne.

Mellersh, D. G., and Heath, M. C. 2003. An investigation into the involvement of defense signalling pathways in components of the nonhost resistance of
Arabidopsis thaliana to rust fungi also reveals a model system for studying rust fungal compatibility. Mol. Plant-Microbe Interact. 16:398-404.

Michelmore, R. W., Christopoulou, M., and Caldwell, K. S. 2013. Impacts of resistance gene genetics, function, and evolution on a durable future. Annu. Rev. Phytopathol. 51:291-319.

Mundt, C. C. 1990. Probability of mutation to multiple virulence and durability of resistance gene pyramids. Phytopathology 80:221-223.

Mundt, C. C. 2002. Use of multiline cultivars and cultivar mixtures for disease management. Annu. Rev. Phytopathol. 40:381-410.

Mundt, C. C. 2014. Durable resistance: A key to sustainable management of pathogens and pests. Infect. Genet. Evol. 27:446-455.

Nemri, A., Saunders, D. G. O., Anderson, C., Upashyaya, N. M., Win, J., Lawrence, G. J., Jones, D. A., Kamoun, S., Ellis, J. G., and Dodds, P. N. 2014. The genome sequence and effector complement of the flax rust pathogen Melampsora lini. Front. Plant Sci. 5:98.

Palloix, A., Ayme, V., and Moury, B. 2009. Durability of plant major resistance genes to pathogens depends on the genetic background, experimental evidence and consequences for breeding strategies. New Phytol. 183:190-199.

Papaïx, J., Burdon, J. J., Zhan, J., and Thrall, P. H. 2015. Crop pathogen emergence and evolution in agro-ecological landscapes. Evol. Appl. 8:385402.

Papaï, J., David, O., Lannou, C., and Monod, H. 2013. Dynamics of adaptation in spatially heterogeneous metapopulations. PLoS One 8:e54697.

Papaï, J., Goyeau, H., Du Cheyron, P., Monod, H., and Lannou, C. 2011. Influence of cultivated landscape composition on variety resistance: An assessment based on wheat leaf rust epidemics. New Phytol. 191:10951107.

Papaï, J., Touzeau, S., Monod, H., and Lannou, C. 2014. Can epidemic control be achieved by altering landscape connectivity in agricultural systems? Ecol. Modell. 284:35-47.

Pariaud, B., Goyeau, H., Halkett, F., Robert, C., and Lannou, C. 2012. Variation in aggressiveness is detected among Puccinia triticina isolates of the same pathotype and clonal lineage in the adult plant stage. Eur. J. Plant Pathol. 134:733-743.

Park, R. F., and Wellings, C. R. 2012. Somatic hybridization in the Uredinales. Annu. Rev. Phytopathology 50:219-239.

Parlevliet, J. E. 2002. Durability of resistance against fungal, bacterial and viral pathogens; present situation. Euphytica 124:147-156.

Pink, D., and Puddephat, I. 1999. Deployment of disease resistance genes by plant transformation-A 'mix and match' approach. Trends Plant Sci. 4: 71-75.

Poland, J. A., and Rife, T. W. 2012. Genotyping-by-sequencing for plant breeding and genetics. Plant Genome 5:92-102.

Rafiqi, M., Ellis, J. G., Ludowici, V. A., Hardham, A. R., and Dodds, P. N. 2012. Challenges and progress towards understanding the role of effectors in plant-fungal interactions. Curr. Opin. Plant Biol. 15:477-482.

Robinson, R. A. 1976. Plant pathosystems. Springer-Verlag, Berlin.

Roelfs, A. P. 1987. Genetic control of phenotypes in wheat stem rust. Annu. Rev. Phytopathol. 26:351-367.

Sapoukhina, N., Durel, C.-E., and Le Cam, B. 2009. Spatial deployment of gene-for-gene resistance governs evolution and spread of pathogen populations. Theor. Ecol. 2:229-238.

Saunders, D. G., Win, J., Cano, L. M., Szabo, L. J., Kamoun, S., and Raffaele, S. 2012. Using hierarchical clustering of secreted protein families to classify and rank candidate effectors of rust fungi. PLoS One 7:e29847.

Schoeny, A., Jumel, S., Rouault, F., Lemarchand, E., and Tivoli, B. 2010. Effect and underlying mechanisms of pea-cereal intercropping on the epidemic development of ascochyta blight. Eur. J. Plant Pathol. 126:317331.

Schoonbeek, H. J., Wang, H. H., Stefanato, F. L., Craze, M., Bowden, S., Wallington, E., Zipfel, C., and Ridout, C. J. 2015. Arabidopsis EF-Tu receptor enhances bacterial disease resistance in transgenic wheat. New Phytol. 206:606-613.

Schouten, H. J., Krens, F. A., and Jacobsen, E. 2006. Cisgenic plants are similar to traditionally bred plants: International regulations for genetically modified organisms should be altered to exempt cisgenesis. Eur. Mol. Biol. Organ. Rep. 7:750-753.

Shafiei, R., Hang, C., Kang, J. G., and Loake, G. J. 2007. Identification of loci controlling non-host disease resistance in Arabidopsis thaliana against the leaf rust pathogen Puccinia triticina. Mol. Plant Pathol. 8:773-784.

Skelsey, P., Rossing, W. A. H., Kessel, G. J. T., and van der Werf, W. 2010. Invasion of Phytophthora infestans at the landscape level: How do spatial scale and weather modulate the consequences of spatial heterogeneity in host resistance? Phytopathology 100:1146-1161.

Sommerhalder, R. J., McDonald, B. A., Mascher, F., and Zhan, J. 2011. Effect of hosts on competition among clones and evidence of differential selection between pathogenic and saprophytic phases in experimental populations of the wheat pathogen Phaeosphaeria nodorum. BMC Evol. Biol. 11:188. 
Sperschneider, J., Ying, H., Dodds, P. N., Donald, D. M., Upadhyaya, N. M., Singh, K. B., Manners, J. M., and Taylor, J. M. 2014. Diversifying selection in the wheat stem rust fungus acts predominantly on pathogen-associated families and reveals candidate effectors. Front. Plant Sci. 5:372.

Sthapit, J., Gbur, E. E., Brown-Guedira, G., Marshall, D. S., and Milus, E. A. 2012. Characterization of resistance to stripe rust in contemporary cultivars and lines of winter wheat from the eastern United States. Plant Dis. 96: 737-745.

Stukenbrock, E. H., Bataillon, T., Dutheil, J. Y., Hansen, T. T., Li, R., Zala, M., McDonald, B. A., Wang, J., and Schierup, M. H. 2011. The making of a new pathogen: Insights from comparative population genomics of the domesticated wheat pathogen Mycosphaerella graminicola and its wild sister species. Genome Res. 21:2157-2166.

Susi, H., Barrès, B., Vale, P. F., and Laine, A.-L. 2015. Co-infection alters population dynamics of infectious disease. Nat. Commun. 6:5975.

Tack, A. J. M., Horns, F., and Laine, A.-L. 2014. The impact of spatial scale and habitat configuration on patterns of trait variation and local adaptation in a wild plant-parasite. Evolution 68:176-189.

Tack, A. J. M., Thrall, P. H., Barrett, L. G., Burdon, J. J., and Laine, A.-L. 2012. Variation in infectivity and aggressiveness in space and time in wild host-pathogen systems - causes and consequences. J. Evol. Biol. 25:1918-1936.

Thordal-Christensen, H. 2003. Fresh insights into processes of nonhost resistance. Curr. Opin. Plant Biol. 6:351-357.

Thrall, P. H., and Burdon, J. J. 2003. Evolution of virulence in a plant hostpathogen metapopulation. Science 299:1735-1737.

Thrall, P. H., and Burdon, J. J. 2004. Host-pathogen life-history interactions affect biological control success. Weed Technol. 18:1269-1274.

Thrall, P. H., Laine, A.-L., Ravensdale, M., Nemri, A., Dodds, P. N., Barrett, L. G., and Burdon, J. J. 2012. Rapid genetic change underpins antagonistic coevolution in a natural host-pathogen metapopulation. Ecol. Lett. 15: 425-435.

Thrall, P. H., Oakeshott, J. G., Fitt, G., Southerton, S., Burdon, J. J., Sheppard, A., Russell, R. J., Zalucki, M., Heino, M., and Denison, R. F. 2011. Evolution in agriculture-The application of evolutionary approaches to the management of biotic interactions in agro-ecosystems. Evol. Appl. 4:200-215.

Tripathi, J. N., Lorenzen, J., Bahar, O., Ronald, P., and Tripathi, L. 2014. Transgenic expression of the rice Xa21 pattern-recognition receptor in banana (Musa sp.) confers resistance to Xanthomonas campestris pv. musacearum. Plant Biotechnol. J. 12:663-673

Ullstrup, A. J. 1972. The impacts of the southern corn leaf blight epidemics of 1970-1971. Annu. Rev. Phytopathol. 10:37-50.

van den Berg, F., Gaucel, S., Lannou, C., Gilligan, C. A., and van den Bosch, F. 2013. High levels of auto-infection in plant pathogens favour short latent periods: A theoretical approach. Evol. Ecol. 27:409-428.

van den Bosch, F., and Gilligan, C. 2003. Measures of durability of resistance. Phytopathology 93:616-625.

van der Plank, J. E. 1963. Plant Diseases: Epidemics and Control. Academic Press, New York.

Varshney, R. K., Terauchi, R., and McCouch, S. R. 2014. Harvesting the promising fruits of genomics: Applying genome sequencing technologies to crop breeding. PLoS Biol. 12:e1001883.
Villaréal, L. M. M. A., and Lannou, C. 2000. Selection for increased spore efficacy by host genetic background in a wheat powdery mildew population. Phytopathology 90:1300-1306.

Vleeshouwers, V. G. A. A., and Oliver, R. P. 2014. Effectors as tools in disease resistance breeding against biotrophic, hemibiotrophic, and necrotrophic plant pathogens. Mol. Plant-Microbe Interact. 27:196-206.

Wang, B., Brubaker, C. L., Tate, W., Woods, M. J., and Burdon, J. J. 2008. Evolution of virulence in Fusarium oxysporum f.sp. vasinfectum using serial passage assays through susceptible cotton. Phytopathology 98:296-303.

Watson, I. A. 1981. Wheat and its rust parasites in Australia. Pages 129-147 in: Wheat science-Today and tomorrow. Evans, L. T., and Peacock, W. J., eds. Cambridge University Press, Cambridge.

Wolfe, M. S. 1985. The current status and prospects of multiline cultivars and variety mixtures for disease resistance. Annu. Rev. Phytopathol. 23:251-273.

Wulff, B. B. H., and Moscou, M. J. 2014. Strategies for transferring resistance into wheat: From wide crosses to GM cassettes. Front. Plant Sci. 5:692.

Yang, L., Gao, F., Shang, L., Zhan, J., and McDonald, B A. 2013. Association between virulence and triazole resistance in pathogenic fungus Mycosphaerella graminicola. PLoS ONE 8:e0059568.

Yang, L. N., McLellan, H., Naqvi, S., He, Q., Boevink, P. C., Armstrong, M., Giuliani, L. M., Zhang, W., Tian, Z. D., Zhan, J., Gilroy, E. M., and Birch, P. R. J. 2016. Potato NPH3/RPT2-like protein StNRL1, targeted by a Phytophthora infestans RXLR effector, is a susceptibility factor. Plant Physiol. 171:645-657.

Zaffarano, P. L., Mc Donald, B. A., and Linde, C. C. 2008. Rapid speciation following recent host shifts in the plant pathogenic fungus Rhynchosporium secalis. Evolution 62:1418-1436.

Zhan, J., and McDonald, B. A. 2013. Experimental measures of pathogen competition and relative fitness. Annu. Rev. Phytopathol. 51:131-153.

Zhan, J., Mundt, C. C., Hoffer, M. E., and McDonald, B. A. 2002. Local adaptation and effect of host genotype on the rate of pathogen evolution: An experimental test in a plant pathosystems. J. Evol. Biol. 15:634-647.

Zhan, J., Thrall, P. H., and Burdon, J. J. 2014. Achieving sustainable plant disease management through evolutionary principles. Trends Plant Sci. 19:570-575.

Zhan, J., Thrall, P. H., Papaïx, J., Xie, L., and Burdon, J. J. 2015. Playing on a pathogen's weakness-Using evolution to guide sustainable plant disease control strategies. Annu. Rev. Phytopathol. 53:19-43.

Zhan, J., Torriani, S. F. F., and McDonald, B. A. 2007. Significant difference in pathogenicity between MAT1-1 and MAT1-2 isolates in the wheat pathogen Mycosphaerella graminicola. Fungal Genet. Biol. 44:339-346.

Zhan, J., Yang, L., Zhu, W., Shang, L., and Newton, A. C. 2012. Pathogen populations evolve to greater race complexity in agricultural systemsEvidence from analysis of Rhynchosporium secalis virulence data. PLoS One 7:e38611.

Zhu, S., Ying, L., Vossen, J. H., Visser, R. G. F., and Jacobsen, E. 2012. Functional stacking of three resistance genes against Phytophthora infestans in potato. Transgenic Res. 21:89-99.

Zhu, Y., Chen, H., Fan, J., Wang, Y., Li, Y., Chen, J., Fan, J. X., Wang, Y. Y., Li, Y., Chen, J. B., Fan, J. X., Yang, S. S., Hu, L. P., Leung, H., Mew, T. W., Teng, P. S., Wang, Z. H., and Mundt, C. C. 2000. Genetic diversity and disease control in rice. Nature 406:718-722. 